\title{
Application of processed organic municipal solid waste on agricultural land - a scenario analysis
}

\author{
Sander Bruun ${ }^{\mathrm{a}, *}$, Trine Lund Hansen ${ }^{\mathrm{b}}$, Thomas H. Christensen ${ }^{\mathrm{b}}$, Jakob Magid ${ }^{\mathrm{a}}$ and Lars S. Jensen ${ }^{\mathrm{a}}$ \\ ${ }^{a}$ Department of Agricultural Sciences, Royal Veterinary and Agricultural University, Thorvaldsensvej 40, DK-1871 Frederiksberg C, Denmark \\ E-mail: sab[a]kvl.dk \\ ${ }^{b}$ Environment and Resources, Technical University of Denmark, DTU Building 115, DK-2800 Lyngby, Denmark
}

\begin{abstract}
Source separation, composting and anaerobic digestion, with associated land application, are increasingly being considered as alternative waste management strategies to landfilling and incineration of municipal solid waste (MSW). Environmental life cycle assessments are a useful tool in political decision-making about waste management strategies. However, due to the diversity of processed organic MSW and the situations in which it can be applied, the environmental impacts of land application are very hard to determine by experimental means. In the current study, we used the agroecosystem model Daisy to simulate a range of different scenarios representing different geographical areas, farm and soil types under Danish conditions and legislation. Generally, the application of processed organic MSW resulted in increased emissions compared with the corresponding standard scenarios, but with large differences between scenarios. Emission coefficients for nitrogen leaching to the groundwater ranged from 0.03 to 0.87 , while those for nitrogen lost to surface waters through tile drains ranged from 0 to 0.30 . Emission coefficients for $\mathrm{N}_{2} \mathrm{O}$ formation ranged from 0.013 to 0.022 and for ammonia volatilization from 0.016 to 0.11 . These estimates are within reasonable range of observed values under similar conditions. Furthermore, a sensitivity analysis showed that the estimates were not very sensitive to the mineralization dynamics of the processed organic MSW. The results show that agroecosystem models can be powerful tools to estimate the environmental impacts of land application of processed MSW under different conditions. Despite this, agroecosystem models have only been used to a very limited degree for this purpose.
\end{abstract}

Keywords: compost, anaerobic digestion, agroecosystem model, Daisy

\section{Introduction}

In most parts of the world, municipal solid waste (MSW) is largely incinerated or landfilled. However, increased attention has been given to alternative waste management options such as source separation into organic and inorganic fractions followed by either composting or anaerobic digestion with accompanying biogas production. The number of composting facilities and the amount of source-separated and composted MSW has been increasing in many countries of Europe [1,2] and in the United States [3]. The European Community has initiated a consultative process which will assist in the creation of new policies for waste prevention and recycling [4]. Composting and anaerobic digestion of MSW are strategies that are likely to be employed to reduce waste generation and to recycle nutrients.

Application of composted MSW to agricultural land has several beneficial effects. Generally, the compost increases soil fertility by adding nutrients such as $\mathrm{N}, \mathrm{P}$ and $\mathrm{K}$, thus substituting mineral fertilizers [5,6]. Addition of compost also increases plant health primarily by protection against plant pathogens $[7,8]$. Furthermore, the addition of organic materials and the associated increase in soil organic matter (SOM) has been associated with many positive effects such as improved soil structure, increased water holding capacity and infiltration, increased workability and reduced

\footnotetext{
* Corresponding author.
}

erosion [9-11]. However, application of composted MSW is also associated with a range of negative environmental impacts. Heavy metals and organic compounds from the compost can potentially migrate to drinking water and accumulate in food crops $[12,13]$. Increased leaching of nitrogen after application of composted MSW poses a problem with eutrophication of aquatic environments such as streams, lakes and estuaries [14,15]. Likewise, increased volatilization of ammonia may also lead to eutrophication of sensitive ecosystems. Finally, increased production of greenhouse gasses such as $\mathrm{CO}_{2}, \mathrm{CH}_{4}$ and $\mathrm{N}_{2} \mathrm{O}$ after application of composted MSW exacerbates problems with global warming $[16,17]$. Some of the trace gasses also participate in the depletion of stratospheric ozone. Limited information is available about the effects of application of anaerobically digested MSW, but many of the effects are likely to be the same as those of composted MSW.

The environmental impacts of composting or anaerobic digestion and application of the processed organic MSW on agricultural land can be compared with those of incineration, landfilling and other alternative scenarios in life cycle assessments (e.g., $[18,19])$. These assessments should include the environmental impacts of land application of the processed organic MSW. However, these impacts are difficult to assess by experimental means for several reasons. First, they can only be assessed under field conditions, with associated problems in terms of variation in climate and heterogeneity of the experimental area. Furthermore, there is a wide range of situations such as different climates, soil types, and crop rotations where 
compost can be applied. This means that the impacts can be very dependent on the specific situation in which the material is applied. Finally, many of the environmental impacts such as nitrogen leaching and denitrification are very difficult to measure under field conditions, and some of them only manifest themselves over extended periods. This means that it is a major task to assess the environmental impact of land application of the processed organic MSW in a specific situation by experimental means. A potential alternative is to assess the environmental impacts of the specific situation through simulation with an agroecosystem model. In such models, the information from a large range of different experiments under different conditions has been integrated through model development, parameterization and calibration. The impact of land application of the processed organic MSW can be evaluated in scenarios prepared for the simulation model. A complex agroecosystem model called "Daisy" was used for the analysis performed here. The model has been used extensively for environmental impact assessment; e.g., [20-23].

The purpose of this study is to use data on the $\mathrm{C}$ and $\mathrm{N}$ mineralization dynamics of composted and anaerobically digested organic MSW from the literature to obtain parameters for Daisy to describe the patterns. Subsequently, the model will be used to simulate a range of different realistic scenarios under Danish conditions with and without application of processed organic MSW and the scenarios generated will be used to assess and compare the environmental impacts.

\section{Materials and methods}

\subsection{The Daisy model}

The Daisy model is a one-dimensional, deterministic agro-ecosystem model that includes a hydrological model, a crop model, a mineral nitrogen model, and an SOM model [24]. The hydrological model simulates soil temperature, evapotranspiration, and soil water transport using Richard's equation. The nitrogen model simulates nitrification and denitrification and transport of ammonium and nitrate using the convection-dispersion equation. Nitrification is modeled by saturation kinetics depending on the ammonium concentration, the maximum nitrification rates depending on soil temperature and soil water pressure potential (which is related to oxygen concentration). Potential denitrification is a function of soil respiration, whereas actual denitrification is dependent on diffusion of nitrate to anaerobic micro sites, which is assumed to be proportional to the nitrate concentration. Nitrous oxide formation associated with nitrification and denitrification is modeled as a fraction of the nitrogen flux through each process. The time step of the simulations is one hour. Daisy has performed well in several model comparisons for both short- and long-term nutrient and SOM dynamics [2527]. The model can be downloaded free of charge at http://www.dina.kvl.dk/ daisy.

The SOM model simulates mineralization of nitrogen and carbon. The SOM model partitions organic matter into two added organic matter pools (AOM1 and AOM2), two

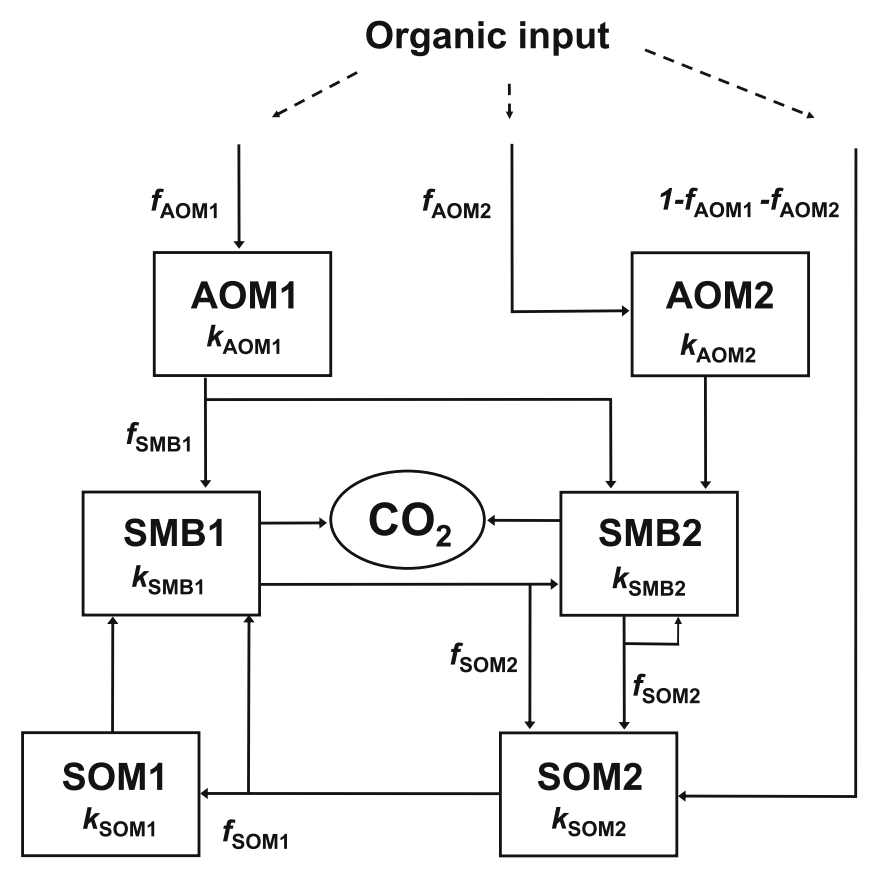

Figure 1. The organic matter model of Daisy. $\mathrm{AOM}=$ added organic matter, $\mathrm{SMB}=$ soil microbial biomass, $\mathrm{SOM}=$ soil organic matter. 
soil microbial biomass pools (SMB1 and SMB2), and two SOM pools (SOM1 and SOM2), see figure 1. Each of the model pools decays by first order kinetics and has a fixed $\mathrm{C} / \mathrm{N}$ ratio that defines the nitrogen dynamics of the model. The SOM model was recently recalibrated and validated using data from Danish long-term experiments [28]. New material, such as processed organic MSW, enters the model through the AOM1 and AOM2 pools. Furthermore, some material may enter directly into the SOM2 pool. It is the distribution of the added materials between these pools, their turnover rates, and $\mathrm{C} / \mathrm{N}$ ratios that determine the $\mathrm{C}$ and $\mathrm{N}$ mineralization dynamics of the added material.

\subsection{Scenarios}

To assess the consequences of application of composted and anaerobically digested organic MSW under Danish conditions and legislation we developed a range of different scenarios. The purpose of these scenarios was to represent a range of different realistic conditions under the waste products may be applied in Denmark.

Basic scenarios were developed representing the 16 most prevalent combinations of farms with predominantly pig, plant, and dairy production in two different climate zones (East Denmark with an average precipitation of 661 $\mathrm{mm}_{\text {year }}{ }^{-1}$ and West Denmark with an average precipitation of $991 \mathrm{~mm} \mathrm{year}^{-1}$ ) and on two different soil types (sandy and loamy) (figure 2). For the livestock production farms, scenarios with both average and maximum livestock density permitted by existing regulations were included. The average livestock density on Danish farms in 2003 was found to be 0.89 livestock unit ha ${ }^{-1}$ [29], whereas the density permitted by regulations is 1.7 livestock units $\mathrm{ha}^{-1}$ for dairy farms and 1.4 livestock units $\mathrm{ha}^{-1}$ for pig farms [30]. A livestock unit corresponds to a nitrogen excretion in manure of approximately $100 \mathrm{~kg} \mathrm{~N}$ year $^{-1}$.

Realistic crop rotations were constructed to be typical rotations for the climatic zones and farm types in question (table 1). The amounts of nitrogen in fertilizer applied to the different crops were calculated on the basis of Danish fertilizer legislation [30]. According to the regulations, accounts must be kept regarding the nitrogen fertilizer applied to the fields of a farm. Each crop can be supplied with a specific maximum amount of nitrogen (N-norm) depending on the preceding crop and the soil type. Nitrogen from different organic fertilizers is accounted for with different use efficiencies (i.e., fraction of $\mathrm{N}$ in the organic material counting as mineral fertilizer in the $\mathrm{N}$ accounts). These efficiencies are 0.75 for pig slurry and 0.7 for cattle slurry. By assuming that the livestock units consisted of dairy cows (without heifers) in a barn with fixed positions and slatted floor and feeding hogs in a barn with fully slatted floor, the amount of slurry produced on each respective farm type was calculated according to the regulations. For farms with an average livestock density, this resulted in $94.6 \mathrm{~kg} \mathrm{~N} \mathrm{ha}^{-1}$ as slurry for dairy farms and $85.5 \mathrm{~kg} \mathrm{~N} \mathrm{ha}^{-1}$ as slurry for pig farms. The corresponding numbers for the farms with maximum livestock densities were $180.7 \mathrm{~kg} \mathrm{~N} \mathrm{ha}^{-1}$ for dairy farms and $134.6 \mathrm{~kg} \mathrm{~N}^{-1}$ for pig farms.

The calculated amount of slurry produced at the farms was distributed in the crop rotations and the remaining $\mathrm{N}$ permitted by regulations [30] was supplied as mineral fertilizer. Fertilizers and slurry were applied in accordance with principles used in normal farm practice in Denmark. The principles used were: (1) Slurry was preferentially given to spring-sown crops, because the application can be followed by plowing which reduces ammonia volatilization. However, the year where processed organic MSW was applied, supplementary fertilization was preferentially given as mineral fertilizer, even though this year had a spring-sown crop. This was done to minimize the differences in the distribution of slurry applications between scenarios with application of processed MSW and the corresponding standard scenario. (2) Grazed grass/clover was not fertilized with slurry except for $80 \mathrm{~kg} \mathrm{ha}^{-1}$ year $^{-1}$ corresponding to natural defecation and urination of the animals during grazing.

We expanded upon the basic scenarios by adding scenarios with composted and anaerobically digested organic MSW applications. This was done by one application of processed organic MSW in the first year of the crop rotation, which had a spring-sown crop allowing spring application of the processed organic waste. Accord-

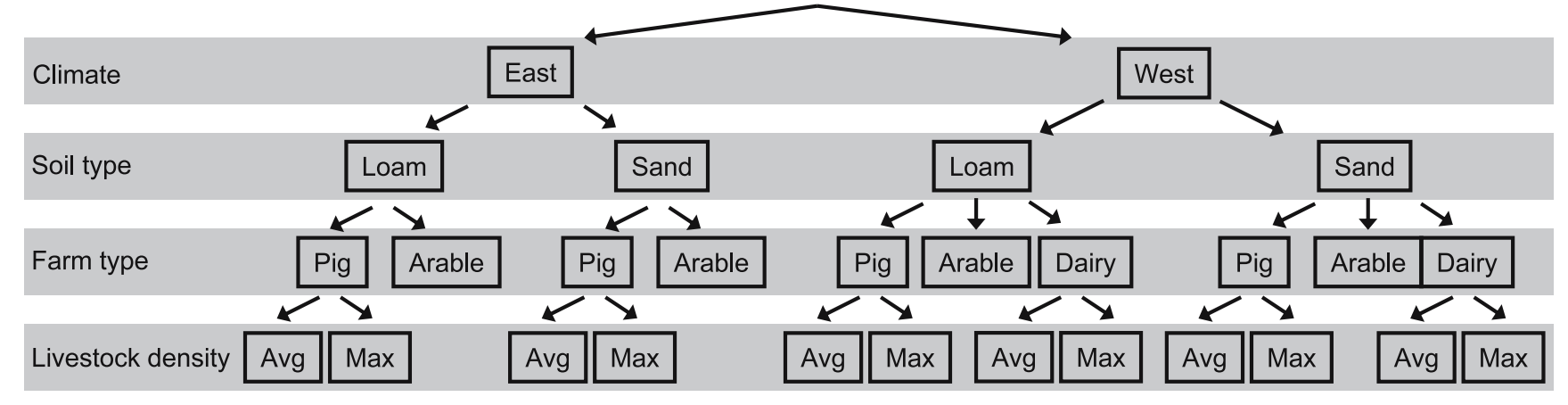

Figure 2. Basic scenarios with combinations of geographical areas in Denmark (climate), soil and farm types, and livestock densities. Max $=$ maximum allowed livestock density according to Danish legislation, Avg = average Danish livestock density. 
Table 1

Crop rotations used in different climate and farm type scenarios.

\begin{tabular}{|c|c|c|c|}
\hline \multirow[t]{2}{*}{ Year in rotation } & \multirow{2}{*}{$\frac{\text { East climate }}{\text { Arable and pig farms }}$} & \multicolumn{2}{|c|}{ West climate } \\
\hline & & Arable and pig farms & Dairy farms \\
\hline 1 & Spring barley & Spring barley & Silage corn \\
\hline 2 & Winter barley & Pea & Barley whole-crop silage, undersown \\
\hline 3 & Winter wheat & Winter wheat & Grass/clover pasture (cut) \\
\hline 4 & Sugar beet & Potato & Grass/clover pasture (grazed) \\
\hline 5 & Spring barley & Spring barley, undersown & Spring barley \\
\hline 6 & Winter wheat & Ryegrass & Winter wheat \\
\hline 7 & Winter wheat & Winter rape & \\
\hline 8 & Ryegrass & Winter wheat & \\
\hline
\end{tabular}

The crop rotations were constructed to be typical for the Danish climatic zones and farm types studied.

ing to the regulations a maximum of $170 \mathrm{~kg}$ total $\mathrm{N}^{-1}$ can be supplied as organic fertilizers on land where waste derived material is supplied and no other organic fertilizers are allowed that year. The regulation $\mathrm{N}$ use efficiency that must be assigned in the $\mathrm{N}$ accounts is $20 \%$ for compost and $40 \%$ for other organic manures such as anerobically digested MSW.

We applied amounts corresponding to the maximum allowed nitrogen rate of $170 \mathrm{~kg} \mathrm{ha}^{-1}$ in the scenarios with addition of composted or anaerobically digested MSW. The $\mathrm{N}$ added as waste treatment products substituted for $\mathrm{N}$ applied in the basic scenario as mineral fertilizer according to the regulations. The slurry produced on the livestock farms was subsequently distributed in the other years of the crop rotation.

\subsection{Model setup}

We used the Daisy version 3.47 for the current application of the model. The application complies with the rules of application in the manual [31]. The application manual is accompanied by a number of computer libraries containing standard parameterizations of a range of soil types and crops.

The climatic data were taken from Børgesen et al. [21] and is the same 'normalized' year repeated every year. The precipitation of the normalized year was adapted to the East and West Denmark climates by multiplying it by a calibration factor calculated from the average monthly precipitation in the area. The annual precipitation for these two climate zones is $661 \mathrm{~mm}$ for East Denmark and 991 $\mathrm{mm}$ for West Denmark. To make sure the amount of the water and nitrogen balances had equilibrated with the crop rotation and management, we chose to run the rotation two times prior to the simulation period, resulting in an initialization period of 16 years for the arable and pig rotations and 12 years for the dairy rotations.

To describe the hydraulic and thermal properties of the soils, the standard Daisy library contains a number of parameterizations for typical Danish soil types. We used the standard parameterization of a coarse sand soil $(3.9 \%$ clay, $6.4 \%$ silt, $20.4 \%$ fine sand, $66.6 \%$ coarse sand, and a bulk density of $1.45 \mathrm{~g} \mathrm{~cm}^{-3}$ in the top soil) and a sandy clay loam ( $17.5 \%$ clay, $25.8 \%$ silt, $30.5 \%$ fine sand, $23.7 \%$ coarse sand, and a bulk density of $1.53 \mathrm{~g} \mathrm{~cm}^{-3}$ in the topsoil) under Danish conditions. The parameterization of the deeper horizons of these particular soil types also followed the standard parameterization. Most sandy soils are not subjected to tile drainage and therefore the lower boundary condition was specified as free drainage (i.e., a pressure boundary) in these soils. In contrast, most loamy soils in Denmark are tile drained and therefore we specified this as the lower boundary condition. To make sure that the tile drains were set up properly, we calibrated the conductance and the depth of the aquitard (water restricting layer) so that approximately half of the water percolating through the soil drained through the tiles [32]. We achieved this by using an aquitard depth of $2.5 \mathrm{~m}$ and a conductance value of $7.5 \times 10^{-4} \mathrm{~cm} \mathrm{~h}^{-1}$ under the East Denmark climate and a value of $2.5 \times 10^{-4} \mathrm{~cm} \mathrm{~h}^{-1}$ under

Table 2

Values of the carbon content $\left(\mathrm{kg} \mathrm{m}^{-2}\right)$ in the different scenarios used to initialize the simulations (from Heidmann et al. [33]).

\begin{tabular}{|c|c|c|c|c|c|c|}
\hline \multirow[t]{2}{*}{ Depth $(\mathrm{cm})$} & \multicolumn{3}{|c|}{ Loam } & \multicolumn{3}{|c|}{ Sand } \\
\hline & Pig & Arable & $\overline{\text { Dairy }}$ & Pig & Arable & $\overline{\text { Dairy }}$ \\
\hline $0-25$ & 5.81 & 5.89 & 5.32 & 6.71 & 5.76 & 9.97 \\
\hline $25-50$ & 4.39 & 4.35 & 3.57 & 4.95 & 4.20 & 7.46 \\
\hline $50-75$ & 2.50 & 3.24 & 2.79 & 2.78 & 2.66 & 2.93 \\
\hline $75-100$ & 1.39 & 1.39 & 1.39 & 1.28 & 1.28 & 1.28 \\
\hline $0-300$ & 17.4 & 18.1 & 16.3 & 19.4 & 17.6 & 25.3 \\
\hline
\end{tabular}

The values from 0 to $300 \mathrm{~cm}$ are those calculated by Daisy after the initialization of the model by integrating the other values from 0 to $300 \mathrm{~cm}$. 


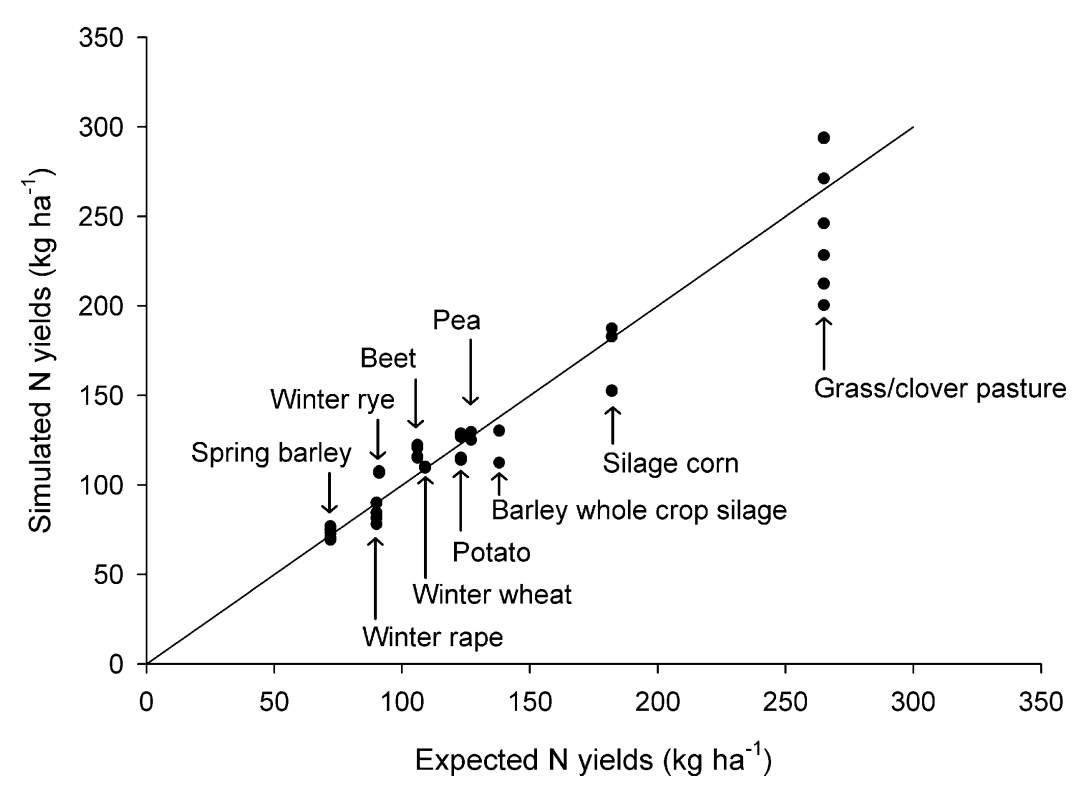

Figure 3. Comparison of expected and simulated crop $\mathrm{N}$ yields in all standard scenarios without application of processed organic MSW.

the West Denmark climate. The maximum rooting depth is dependent on the soil type. The values used were the standard values, with $50 \mathrm{~cm}$ for the sandy soil and $100 \mathrm{~cm}$ for the loamy soil.

The soil organic carbon contents were taken as the average values for soils with similar texture from Heidmann et al. [33]. The values were converted to $\mathrm{kg} \mathrm{m}^{-2}$ using the bulk densities of the standard soils. This led to the values given in table 2. The quantity of the organic matter inputs before the onset of the simulation influences the distribution of carbon between the SOM pools of the model [34]. Therefore, an estimate of the size of the inputs during the period before the onset of the simulations is needed for initialization of the SOM model. Realistic values of these inputs were assessed by simulating the crop rotations once and assuming that these were the inputs before the simulations started.

Standard parameterizations of crops and management dates for tillage, sowing and harvest were used [31]. Most sandy soils in Denmark are subjected to irrigation in periods with little precipitation. We used the standard recommendations on the sandy soil where irrigation is performed each time the water pressure potential is below $-400 \mathrm{~cm}$ at a depth of $30 \mathrm{~cm}$. At each irrigation event 30 $\mathrm{mm}$ was applied, but only in the recommended irrigation periods.

The standard parameterizations in DHI [31] were used to define the parameters of the slurry applications. Standard dates of application of organic and mineral fertilizers and contents of ammonia, nitrate, and water were used. Some autumn-sown crops are usually supplied with an early application of fertilizer in March, followed by a later application at the end of April. In these instances we applied $30 \%$ of the total application early and the rest at the later application. The application of fertilizer on the pastures was split into four applications, namely, 30\% 15 March, 30\% April 1, 20\% 1 May, and 20\% 15 August.

Nitrogen crop yields were corrected to be in accordance with average yields measured for the crop in question during the period 1990-2001 [31]. In accordance with this, we calibrated the photosynthesis efficiency at different development stages of the crops (the DSeff parameters) in order to obtain reasonable agreement between simulated and expected $\mathrm{N}$ yields. A comparison between the expected and simulated $\mathrm{N}$ yields after the calibration is shown in figure 3. After the calibration, there appears to be reasonable agreement between the expected and simulated $\mathrm{N}$ yields, except for the grass/clover pasture. We attempted to calibrate the clover and grass modules to agree with the expected values, but it was impossible to avoid higher simulated yields in the second year compared to the first year of grass/clover. Therefore, we restricted the calibration to make the average $\mathrm{N}$ yield of the two consecutive grass/clover pastures correspond to the expected value.

\subsection{Calibration of mineralization dynamics of composted and anaerobically digested MSW}

The application manual for Daisy provides a parameterization of source-separated composted MSW using data on its chemical composition from a number of different sources [31]. However, as the exact mineralization pattern is of importance in the current context, we recalibrated the parameters pertaining to the mineralization dynamics.

To obtain data for the calibration we compiled data from different incubation experiments measuring either $\mathrm{C}$ or $\mathrm{N}$ mineralization of relevant composted organic MSW products. Composted MSW can potentially have very different mineralization dynamics depending on the initial material, the bulking agent used and the maturity of the 
product. Therefore we selected experiments that fulfilled a number of criteria. To avoid an immobilization phase and other adverse effects on crop yields, mature composts are generally recommended for agricultural purposes [35]. Furthermore, a bulking agent with a high $\mathrm{C} / \mathrm{N}$ ratio is usually used to ensure sufficient aeration during the composting process. Finally, we were interested in the long-term dynamics and therefore the experiments had to cover a sufficient time span. We used data on C mineralization of the compost in the Orthic Luvisol from Leifeld et al. [36] and data on $\mathrm{C}$ and $\mathrm{N}$ mineralization from the mature compost at $15^{\circ} \mathrm{C}$ from Chodak et al. [37]. Finally, we used the data on the mature household waste compost from Asdal et al. [38]. The data from these incubations could be fitted with the same simulation because the clay content does not influence the decomposition of AOM pools in the Daisy model, and all incubations were done under optimal water conditions, and the temperature was almost identical in the different incubations. The fitting was done by the method of least squares and by modifying the turnover rates of AOM1 and $\mathrm{AOM} 2$, the $\mathrm{C} / \mathrm{N}$ ratio of $\mathrm{AOM} 1$, and the fraction of $\mathrm{AOM}$ diverted to AOM1 and AOM2.

We were only able to find a very limited number of papers with useful data on the mineralization pattern of anaerobically digested organic MSW. Therefore, we applied the parameters pertaining to the rate of decomposition of AOM1 and AOM2 from the composted MSW and modified the parameters pertaining to the chemical composition in accordance with unpublished data from measurements on anaerobically digested organic MSW.

\subsection{Sensitivity analysis}

To test the influence of the mineralization dynamics of the processed MSW on the results we performed a sensitivity analysis. To do this, we needed to change the course of the $\mathrm{N}$ mineralization so that it covered a range that might be expected due to variation between composted MSW products from different sources. Therefore we ran a simulation with faster mineralization $(+\mathrm{M})$ and a simulation with slower mineralization $(-\mathrm{M})$, spanning a reasonable range of mineralization patterns for both composted and anaerobically digested MSW as shown by the variation in the observations. A range of different parameters in the model can be changed to obtain the different mineralization patterns. We chose to modify the $\mathrm{N}$ mineralization patterns by changing the parameter representing the $\mathrm{C} / \mathrm{N}$ ratio of the AOM1 pool because it can be changed without changing the mineralization pattern of $\mathrm{C}$.

\subsection{Simulations and expression of results}

To assess the environmental impacts of a single application of processed organic MSW, these scenarios started with one application in the first year of the first rotation followed by corresponding crop rotations without any applications. Each of the scenarios was simulated for 100 years and the relevant emissions such as leached $\mathrm{N}$, emitted $\mathrm{N}_{2} \mathrm{O}$ and $\mathrm{CO}_{2}$ were logged. Nitrogen (mainly in the form of $\mathrm{NO}_{3}^{-}$) was considered to be lost from the root zone when it had leached below $3 \mathrm{~m}$. The yearly loss rate due to nitrogen leaching was calculated as the total flux of nitrogen through this boundary divided by the number of simulated years.

The emission coefficient $\left(k_{x}\right)$ of an element $(\mathrm{C}$ or $\mathrm{N})$ in the processed organic MSW through the process $x$ was calculated as:

$$
k_{x}=\frac{E_{x, P}-E_{x, S}}{S_{P}}
$$

where $E_{x, P}$ is the accumulated emission through $x$ in the simulation of the scenario with application of processed organic MSW, $E_{x, S}$ is the emission in the simulation of the corresponding standard scenario and $S_{P}$ is the amount of the element applied as processed organic MSW in the scenarios.

The consequences for $\mathrm{CO}_{2}$ emissions of processed organic MSW application are more complicated. After a single application, all of the carbon in the applied material will eventually be transformed into $\mathrm{CO}_{2}$. However, because some of the carbon is stored in the soil for an appreciable time, the emissions are delayed compared to incineration. Therefore, the amount of $\mathrm{CO}_{2}$ emitted to the atmosphere is dependent on the time frame in which emissions are thought to be relevant. The emission coefficients were calculated for 10, 50 and 100 years to give a fair selection of time frames. Sometimes the environmental impacts are assessed as sequestered carbon, which is closely related to $\mathrm{CO}_{2}$ emissions.

The above data presentation was chosen because of its appropriateness in connection with environmental assessment. As the regulations require proportionately more land for the application of more processed organic MSW, linearity can be assumed and consequently, the coefficients can be used to assess the impact of applying an amount of an element as processed organic $\operatorname{MSW}\left(A_{x, P}\right)$ by:

$$
E_{x}=k_{x} A_{x, P}
$$

where $E_{x}$ is the emission through process $x$ caused by the application of the processed organic MSW and $k_{x}$ is the emission coefficient estimated by equation (1).

\section{Results}

\subsection{Calibration of the mineralization dynamics of processed organic MSW}

Despite differences in origin and composition of the composted organic MSW, the mineralization dynamics during the standard conditions of the incubations still follow the same general pattern (figure 4). Thus, although the composted MSW differed, the approach of fitting the 


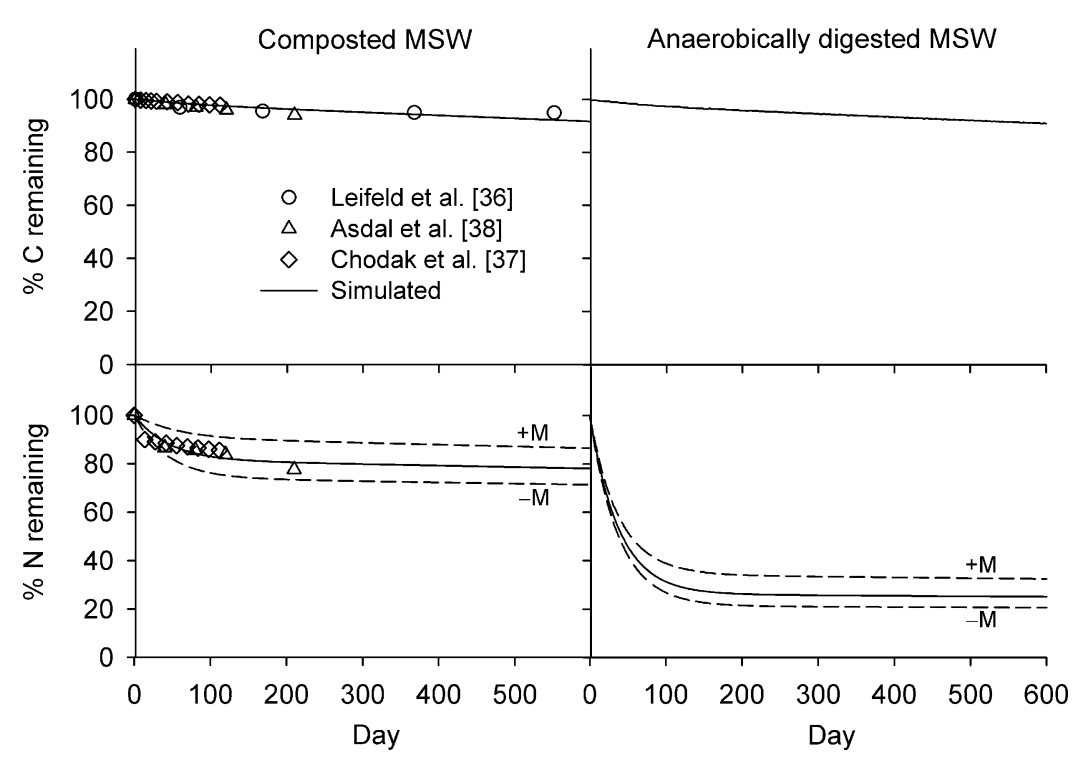

Figure 4. C and $\mathrm{N}$ mineralization of composted organic MSW from different sources and fit of the model after calibration. The simulated C and N mineralization patterns of anaerobically digested MSW and the N mineralization in the simulations used in the sensitivity analysis with faster ( + M) and slower $(-\mathrm{M})$ mineralization are also shown.

model to the data with a single simulation was justified. The model simulations corresponded very well to the observations after calibration of the compost mineralization dynamics (figure 4). The resulting parameters can be found in table 3 . For comparison the old parameters are also shown in table 3, as are data pertaining to the chemical composition of the composted and the anaerobically digested organic MSW. The simulated mineralization dynamics under the standard conditions can be seen in figure 4 . The simulation with faster $(+\mathrm{M})$ and slower $(-\mathrm{M})$ mineralization used in the sensitivity analysis was obtained by changing the parameter representing the $\mathrm{C} / \mathrm{N}$ ratio of the AOM1 pool. For the composted organic MSW, the parameter was changed from 29 to 26 in the $+\mathrm{M}$ simulation and to 32 in the $-\mathrm{M}$ simulation. For the anaerobically digested organic MSW, the parameter was changed from 29 to 22 for the $+\mathrm{M}$ simulation and to 36 for the $-\mathrm{M}$ simulation. The mineralization dynamics of the materials in the resulting simulations are also shown in figure 4.

\subsection{Dynamics of the emissions after application of processed organic MSW}

The pattern of increased emission of pollutants after application of the two types of processed organic MSW in the scenario representing an arable farm in West Denmark on a loamy soil is shown in figure 5, as an example. The increased $\mathrm{N}$ leaching to the groundwater (a), increased $\mathrm{N}$ in drainage water (b), increased $\mathrm{N}_{2} \mathrm{O}$ formation (c) and increased $\mathrm{CO}_{2}$ formation (d) are shown in the figure.

There was a surge of emissions shortly after the application of processed organic MSW, followed by a period of dwindling additional emissions for nitrogen leaching to the groundwater, loss through tile drainage and $\mathrm{N}_{2} \mathrm{O}$ formation. The initial surge of emissions was higher for the anerobically digested MSW than for the composted MSW, whereas the emissions were higher for the compost later in the period.

Table 3

Parameters describing the decomposition of composted MSW found by calibration.

\begin{tabular}{|c|c|c|c|c|}
\hline \multirow[t]{2}{*}{ Parameter } & \multicolumn{3}{|c|}{ Composted MSW } & \multirow{2}{*}{$\frac{\text { Anaerobically digested MSW }}{\text { Total AOM }}$} \\
\hline & Total AOM & AOM1 & AOM2 & \\
\hline Initial fraction & 1 & $0.98(0.72)$ & $0.02(0.18)$ & 1 \\
\hline $\mathrm{C} / \mathrm{N}$ ratio & - & $29(100)$ & - & - \\
\hline Dry matter fraction & 0.50 & - & - & 0.01 \\
\hline Total C fraction & 0.40 & - & - & 0.38 \\
\hline Total $\mathrm{N}$ fraction & 0.019 & - & - & 0.10 \\
\hline $\mathrm{NH}_{4}$ fraction & 0.107 & - & - & 0.5 \\
\hline Turnover rate $\left(\mathrm{h}^{-1}\right)$ & - & $5.0 \times 10^{-6}\left(2.0 \times 10^{-4}\right)$ & $8.0 \times 10^{-4}\left(2.0 \times 10^{-3}\right)$ & - \\
\hline Microbial use efficiency & - & 0.6 & 0.6 & - \\
\hline
\end{tabular}

Most numbers are derived from the standard parameterization [31]. For calibrated parameter value, the original value is given in brackets. AOM = added organic matter. 

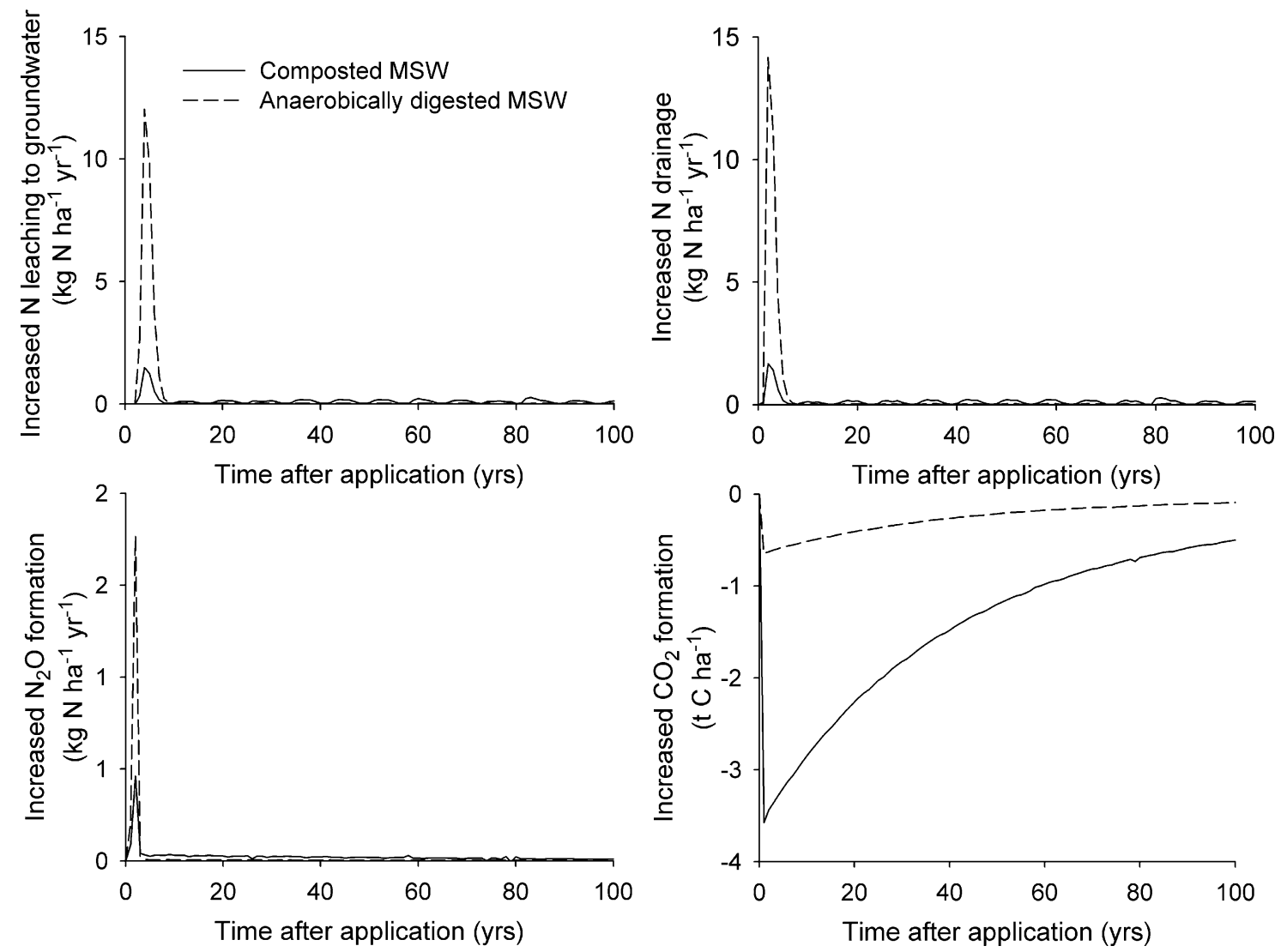

Figure 5. Increased emissions of pollutants after application of composted organic MSW and anaerobically digested organic MSW.

The additional emissions of $\mathrm{CO}_{2}$ in the scenarios with application of processed organic MSW decreased sharply after application because the organic $\mathrm{C}$ in materials was sequestered. Then the additional emissions gradually approached the emissions of the standard scenario as the organic material was decomposed.

\subsection{Nitrogen leaching to the groundwater}

The average rate of nitrogen leaching to the groundwater in the standard scenarios over the simulation period and the emission coefficients are shown in table 4. The leaching rates were higher in the sandy soil, with an average of $81 \mathrm{~kg} \mathrm{~N}^{-1}$ year $^{-1}$, compared to the loamy soil, with an average of $15 \mathrm{~kg} \mathrm{~N}^{-1}$ year $^{-1}$. The leaching rate also increased with increasing livestock density from arable farms to animal farms with average livestock density to livestock farms with maximum livestock density. Furthermore, very large losses were observed on dairy farms on sandy soil with grass/clover in the crop rotation.

The emission coefficients of leached nitrogen $\left(k_{l-N}\right)$ express the extra nitrogen leaching in the scenarios with application of processed organic MSW compared with the corresponding standard scenarios, expressed as a fraction of the nitrogen added with the processed MSW. These emission coefficients were very variable ranging from 0.03 to 0.87 depending on the situation (table 4 ). Reflecting the higher leaching rates, the emission coefficients were also higher on the sandy soil compared to the loamy soil. However, higher animal density did not lead to higher emission coefficients in all the scenarios. Despite exceptions, the emission coefficients were generally higher for composted organic MSW than anaerobically digested organic MSW on the sandy soils, whereas the differences were less marked on the loamy soil.

The sensitivity analysis showed that variation in the mineralization dynamics within a reasonable range only influenced the estimated emission coefficients of nitrogen leaching to a limited extent. The deviations from the calculated emission coefficients in the simulations with the modified mineralization dynamics were generally small and caused a change in the emission coefficients of less than $30 \%$ in all scenarios and in most cases much less.

\subsection{Nitrogen loss through tile drainage}

The average rates of nitrogen loss through tile drainage and surface runoff in the standard scenarios over the simulation period and the emission coefficients of the applied processed MSW through these processes are shown in table 5 .

In none of the scenarios was water lost through surface runoff. Therefore all the losses were through the tile drains. No nitrogen was lost through these processes on the sandy 
Table 4

Average annual leaching rates $\left(r_{l-N}\right)$ of nitrogen in the standard scenarios and the emission coefficients for nitrogen leaching $\left(k_{l-N}\right)$.

\begin{tabular}{|c|c|c|c|c|c|c|c|c|c|c|}
\hline \multirow[t]{2}{*}{ Region } & \multirow[t]{2}{*}{ Farm type } & \multirow[t]{2}{*}{ Soil type } & \multirow[t]{2}{*}{ Livestock density } & \multirow{2}{*}{$\begin{array}{c}r_{l-N} \text { standard } \\
\left(\mathrm{kg} \mathrm{ha}^{-1} \text { year }^{-1}\right)\end{array}$} & \multicolumn{3}{|c|}{ Composted MSW } & \multicolumn{3}{|c|}{ Anaerobically digested MSW } \\
\hline & & & & & $\overline{k_{l-N}}$ & $+\mathrm{M}(\%)$ & $-\mathrm{M}(\%)$ & $\overline{k_{l-N}}$ & $+\mathrm{M}(\%)$ & $-\mathrm{M}(\%)$ \\
\hline \multirow[t]{6}{*}{ East } & \multirow[t]{4}{*}{ Pig } & \multirow[t]{2}{*}{ Loam } & Max & 25.2 & 0.20 & -2.6 & 2.5 & 0.21 & -1.0 & 0.5 \\
\hline & & & Average & 22.2 & 0.22 & -3.4 & -1.4 & 0.22 & -0.5 & 1.2 \\
\hline & & \multirow[t]{2}{*}{ Sand } & Max & 81.7 & 0.61 & -1.2 & 1.1 & 0.46 & 2.8 & 3.3 \\
\hline & & & Average & 76.3 & 0.57 & 8.7 & -0.4 & 0.46 & 1.0 & 3.0 \\
\hline & \multirow[t]{2}{*}{ Arable } & Loam & 0 & 18.9 & 0.20 & 0.2 & 3.5 & 0.22 & -2.6 & 0.5 \\
\hline & & Sand & 0 & 63.9 & 0.62 & -1.3 & 0.9 & 0.45 & -0.6 & 1.2 \\
\hline \multirow[t]{10}{*}{ West } & \multirow[t]{4}{*}{ Dairy } & \multirow[t]{2}{*}{ Loam } & Max & 9.1 & 0.10 & 11.8 & -11.8 & 0.07 & 6.2 & -3.9 \\
\hline & & & Average & 6.7 & 0.03 & 28.8 & -19.8 & 0.04 & -24.7 & 12.3 \\
\hline & & \multirow[t]{2}{*}{ Sand } & Max & 103.9 & 0.86 & -11.3 & -0.1 & 0.61 & -10.2 & 0.6 \\
\hline & & & Average & 90.3 & 0.87 & -7.1 & -23.5 & 0.33 & -6.2 & 7.6 \\
\hline & \multirow[t]{4}{*}{ Pig } & \multirow[t]{2}{*}{ Loam } & Max & 15.8 & 0.04 & -14.8 & 32.2 & 0.15 & -6.4 & 3.8 \\
\hline & & & Average & 12.4 & 0.08 & -28.7 & 19.7 & 0.18 & -5.0 & 2.4 \\
\hline & & \multirow[t]{2}{*}{ Sand } & Max & 85.3 & 0.45 & -4.7 & 0.3 & 0.39 & -1.7 & 1.0 \\
\hline & & & Average & 76.3 & 0.50 & -4.6 & -0.1 & 0.41 & 5.2 & 3.4 \\
\hline & \multirow[t]{2}{*}{ Arable } & Loam & 0 & 11.5 & 0.07 & -25.0 & 21.5 & 0.18 & -5.0 & 2.8 \\
\hline & & Sand & 0 & 67.8 & 0.53 & -6.0 & -2.2 & 0.60 & -1.4 & 2.8 \\
\hline
\end{tabular}

The percentage deviations from these coefficients in the sensitivity analysis are given for the parameterization with faster nitrogen mineralization $(+\mathrm{M})$ and slower nitrogen mineralization $(-\mathrm{M})$.

soils because the tile drains only occurred in the scenarios with loamy soil. The rates of nitrogen loss through tile drainage on loamy soil were all of the same magnitude and follow the same pattern between scenarios as the losses through leaching. In fact, the rates of nitrogen loss through leaching to groundwater and tile drainage on the loamy soil were very highly correlated $(r=0.9994)$. Therefore the rates of loss through drainage on the loamy soil also followed the same pattern as the losses though nitrogen leaching with more lost at higher animal densities. The average rate of nitrogen loss through tile drainage was $16 \mathrm{~kg} \mathrm{~N} \mathrm{ha}^{-1}$ year $^{-1}$ in the standard scenarios. It should be noted that losses to streams and lakes may occur later through recharge from upper groundwater layers. This was not included in the current simulations.

The emission coefficients did not seem to increase with animal density and the results did not indicate that the different mineralization dynamics of anaerobically digested MSW compared to the composted MSW had a definite effect on the emission coefficients.

The variation in the mineralization dynamics tested in the sensitivity analysis did not influence the emission

Table 5

Average annual rates of nitrogen loss through tile drains $\left(r_{r-N}\right)$ in the standard scenarios and the emission coefficients for nitrogen losses through the tile drains $\left(k_{r-N}\right)$.

\begin{tabular}{|c|c|c|c|c|c|c|c|c|c|c|}
\hline \multirow[t]{2}{*}{ Region } & \multirow[t]{2}{*}{ Farm type } & \multirow[t]{2}{*}{ Soil type } & \multirow[t]{2}{*}{ Livestock density } & \multirow{2}{*}{$\begin{array}{c}r_{r-N} \text { Standard } \\
\left(\mathrm{kg} \mathrm{ha}^{-1} \text { year }^{-1}\right)\end{array}$} & \multicolumn{3}{|c|}{ Composted MSW } & \multicolumn{3}{|c|}{ Anaerobically digested MSW } \\
\hline & & & & & $\overline{k_{r-N}}$ & $+\mathrm{M}(\%)$ & $-\mathrm{M}(\%)$ & $\overline{k_{r-N}}$ & $+\mathrm{M}(\%)$ & $-\mathrm{M}(\%)$ \\
\hline \multirow[t]{6}{*}{ East } & \multirow[t]{4}{*}{ Pig } & \multirow[t]{2}{*}{ Loam } & Max & 26.2 & 0.24 & -11.2 & 10.2 & 0.22 & -1.4 & 6.8 \\
\hline & & & Average & 23.0 & 0.30 & -7.3 & -5.2 & 0.27 & -1.8 & 0.0 \\
\hline & & \multirow[t]{2}{*}{ Sand } & Max & 0.0 & 0.00 & - & - & 0.00 & - & - \\
\hline & & & Average & 0.0 & 0.00 & - & - & 0.00 & - & - \\
\hline & \multirow[t]{2}{*}{ Arable } & Loam & 0 & 19.3 & 0.20 & 6.2 & 10.9 & 0.25 & -8.1 & -0.4 \\
\hline & & Sand & 0 & 0.0 & 0.00 & - & - & 0.00 & - & - \\
\hline \multirow[t]{10}{*}{ West } & \multirow[t]{4}{*}{ Dairy } & \multirow[t]{2}{*}{ Loam } & Max & 9.7 & 0.15 & 8.1 & -8.8 & 0.12 & 3.8 & -2.4 \\
\hline & & & Average & 7.5 & 0.04 & 27.5 & -19.0 & 0.04 & -24.1 & 12.4 \\
\hline & & \multirow[t]{2}{*}{ Sand } & Max & 0.0 & 0.00 & - & - & 0.00 & - & - \\
\hline & & & Average & 0.0 & 0.00 & - & - & 0.00 & - & - \\
\hline & \multirow[t]{4}{*}{ Pig } & \multirow[t]{2}{*}{ Loam } & Max & 16.8 & 0.04 & -15.1 & 31.8 & 0.15 & -6.7 & 3.8 \\
\hline & & & Average & 13.4 & 0.08 & -29.0 & 19.5 & 0.19 & -4.8 & 2.6 \\
\hline & & \multirow[t]{2}{*}{ Sand } & Max & 0.0 & 0.00 & - & - & 0.00 & - & - \\
\hline & & & Average & 0.0 & 0.00 & - & - & 0.00 & - & - \\
\hline & \multirow[t]{2}{*}{ Arable } & Loam & 0 & 12.5 & 0.08 & -24.9 & 21.7 & 0.19 & -5.0 & 3.1 \\
\hline & & Sand & 0 & 0.0 & 0.00 & - & - & 0.00 & - & - \\
\hline
\end{tabular}

The percentage deviations from these coefficients in the sensitivity analysis are given for the parameterization with faster nitrogen mineralization $(+\mathrm{M})$ and slower nitrogen mineralization $(-\mathrm{M})$. 
Table 6

Average annual rates of $\mathrm{N}_{2} \mathrm{O}-\mathrm{N}$ formation $\left(r_{f-N_{2} O-N}\right)$ in the standard scenarios and the emission coefficients for $\mathrm{N}_{2} \mathrm{O}-\mathrm{N}$ formation during nitrification $\left(k_{f-N_{2}} \mathrm{O}-\mathrm{N}\right)$.

\begin{tabular}{|c|c|c|c|c|c|c|c|c|c|c|}
\hline \multirow[t]{2}{*}{ Region } & \multirow[t]{2}{*}{ Farm type } & \multirow[t]{2}{*}{ Soil type } & \multirow[t]{2}{*}{ Livestock density } & \multirow{2}{*}{$\begin{array}{l}r_{f-N_{2} O-N} \text { standard } \\
\left(\mathrm{kg} \mathrm{ha}^{-1} \text { year }^{-1}\right)\end{array}$} & \multicolumn{3}{|c|}{ Composted MSW } & \multicolumn{3}{|c|}{ Anaerobically digested MSW } \\
\hline & & & & & $\overline{k_{f-N_{2}} O-N}$ & $+\mathrm{M}(\%)$ & $-\mathrm{M}(\%)$ & $\overline{k_{f-N_{2}} O-N}$ & $+\mathrm{M}(\%)$ & $-\mathrm{M}(\%)$ \\
\hline \multirow[t]{6}{*}{ East } & \multirow[t]{4}{*}{ Pig } & \multirow[t]{2}{*}{ Loam } & Max & 4.2 & 0.014 & 1.3 & -2.2 & 0.014 & 0.0 & -1.1 \\
\hline & & & Average & 3.7 & 0.014 & 2.0 & -1.4 & 0.013 & 1.0 & 0.9 \\
\hline & & \multirow[t]{2}{*}{ Sand } & Max & 4.2 & 0.017 & 2.0 & -0.5 & 0.014 & 0.5 & 0.1 \\
\hline & & & Average & 3.7 & 0.017 & -2.1 & -0.5 & 0.015 & 0.0 & -1.6 \\
\hline & \multirow[t]{2}{*}{ Arable } & Loam & 0 & 2.9 & 0.015 & 2.1 & -2.2 & 0.014 & 1.6 & -0.3 \\
\hline & & Sand & 0 & 2.8 & 0.017 & 1.3 & -0.9 & 0.015 & 0.6 & -0.8 \\
\hline \multirow[t]{10}{*}{ West } & \multirow[t]{4}{*}{ Dairy } & \multirow[t]{2}{*}{ Loam } & Max & 5.1 & 0.016 & 2.4 & 0.7 & 0.017 & -1.2 & -0.7 \\
\hline & & & Average & 4.2 & 0.014 & 0.2 & 3.3 & 0.016 & -3.2 & -1.6 \\
\hline & & \multirow[t]{2}{*}{ Sand } & Max & 5.9 & 0.017 & -4.7 & 8.1 & 0.017 & -6.3 & -3.2 \\
\hline & & & Average & 5.0 & 0.022 & -5.4 & -21 & 0.014 & -10.9 & 0.7 \\
\hline & \multirow[t]{4}{*}{ Pig } & \multirow[t]{2}{*}{ Loam } & Max & 3.8 & 0.015 & -2.4 & 0.2 & 0.015 & 0.2 & -0.2 \\
\hline & & & Average & 3.2 & 0.014 & -0.3 & -0.4 & 0.014 & 0.2 & -0.7 \\
\hline & & \multirow[t]{2}{*}{ Sand } & Max & 4.0 & 0.016 & -0.4 & 0.0 & 0.015 & 0.6 & 0.2 \\
\hline & & & Average & 3.3 & 0.015 & 0.0 & 1.1 & 0.014 & -2.0 & -0.8 \\
\hline & \multirow[t]{2}{*}{ Arable } & Loam & 0 & 2.8 & 0.014 & 0.5 & -0.4 & 0.014 & 0.4 & -0.4 \\
\hline & & Sand & 0 & 2.9 & 0.015 & -0.1 & 1.6 & 0.016 & -0.1 & -1.3 \\
\hline
\end{tabular}

The percentage deviations from these coefficients in the sensitivity analysis are given for the parameterization with faster nitrogen mineralization $(+\mathrm{M})$ and slower nitrogen mineralization $(-\mathrm{M})$.

coefficients through tile drainage very much. Again, the deviations of the calculated emission coefficients in the simulations from the modified mineralization dynamics were small.

\section{5. $\mathrm{N}_{2} \mathrm{O}$ formation}

The average rates of $\mathrm{N}_{2} \mathrm{O}$ formation in the standard scenarios over the simulation period and the emission coefficients are given in table 6 .
The average value of $\mathrm{N}_{2} \mathrm{O}$ emissions from all scenarios was $3.9 \mathrm{~kg} \mathrm{~N}_{2} \mathrm{O}-\mathrm{N} \mathrm{ha}^{-1}$ year $^{-1}$ varying between rates of 2.8 and $5.9 \mathrm{~kg} \mathrm{~N}_{2} \mathrm{O}-\mathrm{N} \mathrm{ha}{ }^{-1}$ year $^{-1}$. The rate of $\mathrm{N}_{2} \mathrm{O}$ formation was dependent on farm type, being lowest on arable farms and gradually increasing with livestock density. In contrast, there was only a marginal effect of soil type. The emission coefficients were almost the same for application of composted organic MSW, with an average of 0.016 , and application of anaerobically digested organic MSW, with an average of 0.015 . There were no

Table 7

Average annual rates of $\mathrm{NH}_{3}-\mathrm{N}$ volatilization $\left(r_{v-\mathrm{NH}_{3}-\mathrm{N}}\right)$ in the standard scenarios and the emission coefficients for $\mathrm{NH}_{3}$ volatilization $\left(k_{v-N H_{3}-N}\right)$.

\begin{tabular}{|c|c|c|c|c|c|c|c|c|c|c|}
\hline \multirow[t]{2}{*}{ Region } & \multirow[t]{2}{*}{ Farm type } & \multirow[t]{2}{*}{ Soil type } & \multirow[t]{2}{*}{ Livestock density } & \multirow{2}{*}{$\begin{array}{c}r_{v-N H_{3}-N} \text { standard } \\
\left(\mathrm{kg} \mathrm{ha}^{-1} \text { year }^{-1}\right)\end{array}$} & \multicolumn{3}{|c|}{ Composted MSW } & \multicolumn{3}{|c|}{ Anaerobically digested MSW } \\
\hline & & & & & $k_{v-\mathrm{NH}_{3}-\mathrm{N}}$ & $+\mathrm{M}(\%)$ & $-\mathrm{M}(\%)$ & $k_{v-H_{3}-N}$ & $+\mathrm{M}(\%)$ & $-\mathrm{M}(\%)$ \\
\hline \multirow[t]{6}{*}{ East } & \multirow[t]{4}{*}{ Pig } & \multirow[t]{2}{*}{ Loam } & $\operatorname{Max}$ & 12.9 & 0.016 & 0 & 0 & 0.075 & 0 & 0 \\
\hline & & & Average & 7.2 & 0.016 & 0 & 0 & 0.075 & 0 & 0 \\
\hline & & \multirow[t]{2}{*}{ Sand } & Max & 12.8 & 0.016 & 0 & 0 & 0.075 & 0 & 0 \\
\hline & & & Average & 7.1 & 0.016 & 0 & 0 & 0.075 & 0 & 0 \\
\hline & \multirow[t]{2}{*}{ Arable } & Loam & 0 & 0.0 & 0.016 & 0 & 0 & 0.075 & 0 & 0 \\
\hline & & Sand & 0 & 0.0 & 0.016 & 0 & 0 & 0.075 & 0 & 0 \\
\hline \multirow[t]{10}{*}{ West } & \multirow[t]{4}{*}{ Dairy } & \multirow[t]{2}{*}{ Loam } & Max & 10.7 & 0.046 & 0 & 0 & 0.105 & 0 & 0 \\
\hline & & & Average & 4.6 & 0.016 & 0 & 0 & 0.075 & 0 & 0 \\
\hline & & \multirow[t]{2}{*}{ Sand } & Max & 11.1 & 0.045 & 0 & 0 & 0.092 & 0 & 0 \\
\hline & & & Average & 4.2 & 0.033 & 0 & 0 & 0.075 & 0 & 0 \\
\hline & \multirow[t]{4}{*}{ Pig } & \multirow[t]{2}{*}{ Loam } & Max & 11.7 & 0.055 & 0 & 0 & 0.114 & 0 & 0 \\
\hline & & & Average & 4.3 & 0.016 & 0 & 0 & 0.075 & 0 & 0 \\
\hline & & \multirow[t]{2}{*}{ Sand } & $\operatorname{Max}$ & 11.7 & 0.051 & 0 & 0 & 0.110 & 0 & 0 \\
\hline & & & Average & 4.2 & 0.016 & 0 & 0 & 0.075 & 0 & 0 \\
\hline & \multirow[t]{2}{*}{ Arable } & Loam & 0 & 0.0 & 0.016 & 0 & 0 & 0.075 & 0 & 0 \\
\hline & & Sand & 0 & 0.0 & 0.016 & 0 & 0 & 0.075 & 0 & 0 \\
\hline
\end{tabular}

The percentage deviations from these coefficients in the sensitivity analysis are given for the parameterization with faster nitrogen mineralization $(+\mathrm{M})$ and slower nitrogen mineralization $(-\mathrm{M})$. 
general trends in the emission coefficients caused by soil type or animal density.

The sensitivity analysis showed that the emission coefficients of $\mathrm{N}_{2} \mathrm{O}$ formation estimated by the model were not sensitive to the mineralization. The calculated emission coefficients in the scenarios with increased or decreased mineralization deviated with less than $7 \%$ from the standard simulations in all the scenarios.

\subsection{Ammonia volatilization}

The average rates of ammonia volatilization in the standard scenarios over the simulation period and the emission coefficients of ammonia volatilization are shown in table 7.

As no ammonia volatilization occurs from mineral fertilizers, the rate of volatilization at the arable farms is

Table 8

Average annual rate of $\mathrm{CO}_{2}-\mathrm{C}$ emission $\left(r_{r-\mathrm{CO}_{2}-C}\right)$ in the standard scenarios and emission coefficients $\left(k_{r-\mathrm{CO}_{2}-C}\right) 10,50$ and 100 years after application.

\begin{tabular}{|c|c|c|c|c|c|c|c|}
\hline \multirow{2}{*}{$\begin{array}{l}\text { Years } \\
\text { after } \\
\text { application }\end{array}$} & \multirow{2}{*}{$\begin{array}{l}\text { Region } \\
\text { type }\end{array}$} & \multirow{2}{*}{$\begin{array}{l}\text { Farm } \\
\text { type }\end{array}$} & \multirow{2}{*}{$\begin{array}{l}\text { Soil } \\
\text { type }\end{array}$} & \multirow{2}{*}{$\begin{array}{c}\text { Livestock } \\
\text { density }\end{array}$} & \multirow{2}{*}{$\begin{array}{c}r_{r-\mathrm{CO}_{2}-\mathrm{C}} \\
\text { standard } \\
\left(\mathrm{kg} \mathrm{ha}^{-1} \text { year }^{-1}\right)\end{array}$} & \multicolumn{2}{|c|}{$k_{r-\mathrm{CO}_{2}-C}$} \\
\hline & & & & & & $\begin{array}{c}\text { Composted } \\
\text { MSW }\end{array}$ & $\begin{array}{l}\text { Anaerobically } \\
\text { digested MSW }\end{array}$ \\
\hline \multirow[t]{16}{*}{10} & \multirow[t]{6}{*}{ East } & \multirow[t]{4}{*}{ Pig } & \multirow[t]{2}{*}{ Loam } & Max & 197 & 0.19 & 0.16 \\
\hline & & & & Average & 168 & 0.21 & 0.21 \\
\hline & & & \multirow[t]{2}{*}{ Sand } & Max & 520 & 0.21 & 0.20 \\
\hline & & & & Average & 528 & 0.22 & 0.21 \\
\hline & & \multirow[t]{2}{*}{ Arable } & Loam & 0 & 187 & 0.20 & 0.21 \\
\hline & & & Sand & 0 & 447 & 0.22 & 0.19 \\
\hline & \multirow[t]{10}{*}{ West } & \multirow[t]{4}{*}{ Dairy } & \multirow[t]{2}{*}{ Loam } & Max & -118 & 0.23 & 0.37 \\
\hline & & & & Average & -55 & 0.21 & 0.22 \\
\hline & & & \multirow[t]{2}{*}{ Sand } & Max & 570 & 0.24 & 0.35 \\
\hline & & & & Average & 640 & 0.23 & 0.30 \\
\hline & & \multirow[t]{4}{*}{ Pig } & \multirow[t]{2}{*}{ Loam } & Max & 152 & 0.20 & 0.14 \\
\hline & & & & Average & 201 & 0.21 & 0.19 \\
\hline & & & \multirow[t]{2}{*}{ Sand } & Max & 474 & 0.21 & 0.18 \\
\hline & & & & Average & 514 & 0.22 & 0.19 \\
\hline & & Arable & Loam & 0 & 229 & 0.20 & 0.20 \\
\hline & & & Sand & 0 & 441 & 0.22 & 0.20 \\
\hline 50 & East & Pig & Loam & Max & 96 & 0.67 & 0.66 \\
\hline & & & & Average & 86 & 0.67 & 0.67 \\
\hline & & & Sand & Max & 333 & 0.72 & 0.70 \\
\hline & & & & Average & 341 & 0.72 & 0.71 \\
\hline & & Arable & Loam & 0 & 117 & 0.66 & 0.67 \\
\hline & & & Sand & 0 & 294 & 0.71 & 0.70 \\
\hline & West & Dairy & Loam & Max & -58 & 0.69 & 0.75 \\
\hline & & & & Average & -1.0 & 0.68 & 0.69 \\
\hline & & & Sand & Max & 488 & 0.75 & 0.83 \\
\hline & & & & Average & 530 & 0.72 & 0.75 \\
\hline & & Pig & Loam & Max & 82 & 0.66 & 0.63 \\
\hline & & & & Average & 104 & 0.66 & 0.66 \\
\hline & & & Sand & Max & 312 & 0.72 & 0.72 \\
\hline & & & & Average & 330 & 0.71 & 0.71 \\
\hline & & Arable & Loam & 0 & 140 & 0.66 & 0.67 \\
\hline & & & Sand & 0 & 284 & 0.71 & 0.70 \\
\hline 100 & East & Pig & Loam & Max & 70 & 0.87 & 0.87 \\
\hline & & & & Average & 71 & 0.87 & 0.88 \\
\hline & & & Sand & Max & 245 & 0.91 & 0.90 \\
\hline & & & & Average & 252 & 0.90 & 0.91 \\
\hline & & Arable & Loam & 0 & 96 & 0.86 & 0.87 \\
\hline & & & Sand & 0 & 215 & 0.91 & 0.90 \\
\hline & West & Dairy & Loam & Max & -48 & 0.87 & 0.90 \\
\hline & & & & Average & -7 & 0.87 & 0.88 \\
\hline & & & Sand & Max & 362 & 0.92 & 0.96 \\
\hline & & & & Average & 387 & 0.92 & 0.98 \\
\hline & & Pig & Loam & Max & 66 & 0.86 & 0.84 \\
\hline & & & & Average & 82 & 0.86 & 0.86 \\
\hline & & & Sand & Max & 232 & 0.91 & 0.91 \\
\hline & & & & Average & 244 & 0.91 & 0.90 \\
\hline & & Arable & Loam & 0 & 111 & 0.86 & 0.86 \\
\hline & & & Sand & 0 & 209 & 0.91 & 0.90 \\
\hline
\end{tabular}


zero and increases with animal density. Soil type does not seem to have an effect.

The standard parameterization of organic fertilizers assumes that $15 \%$ of the ammonium in the organic fertilizers is volatilized as ammonia when surface-applied. Considering the ammonium content of MSW compost this leads to emission coefficients of 0.016 , while the corresponding figure for anaerobically digested MSW is 0.075 . As both types of processed organic MSW are always assumed to be surface-applied, these emission coefficients will be obtained if the processed organic MSW replaces mineral fertilizer. However, on spring-sown crops, animal slurry is usually injected or plowed in immediately after the application and the standard assumption is that no ammonia is volatilized in this situation. Therefore, in scenarios where the application of processed organic MSW imposes a redistribution of slurry from spring-sown to autumn-sown crops, the emission coefficients will be higher because the loss from spring-sown crops is smaller than that from autumn-sown crops. The emission coefficients also increased in some cases with the animal density because the application of processed organic MSW requires more slurry to be reallocated from spring-sown crops to autumn-sown crops when more slurry was applied in the crop rotation.

In the model the volatilization of ammonia is not dependent on the mineralization dynamics at all, as evidenced by the results of the sensitivity analysis, where the deviations of the emission coefficients in simulations with altered mineralization dynamics were all zero. The volatilization is only dependent on the fraction of the material that is supplied as ammonium and therefore the mineralization dynamics do not influence ammonia volatilization.

\section{7. $\mathrm{CO}_{2}$ emissions to the atmosphere}

Table 8 shows the emission rates of $\mathrm{CO}_{2}$ in the standard scenarios and emission coefficients of $\mathrm{CO}_{2}$ to the atmosphere after 10, 50 and 100 years.

Most soils had positive $\mathrm{CO}_{2}$ emission rates, indicating that more $\mathrm{CO}_{2}$ was released through respiration than fixed by photosynthesis. However, this was not the case for the dairy farms on the loamy soil, because of the high inputs of organic matter from the grass/clover in the crop rotation. Generally, the emission rates were higher with higher animal density and higher on sandy than on clayey soil.

The emission coefficients indicated that for composted MSW between 0.19 and 0.25 of the carbon originally supplied had been emitted as $\mathrm{CO}_{2} 10$ years after the application. This gradually increased so that after 50 years between 0.66 and 0.75 had been emitted and the excess carbon in the amended soils was even further reduced after 100 years. Between 0.14 and 0.37 of the carbon supplied by anaerobically digested MSW compost had been emitted as $\mathrm{CO}_{2}$ after 10 years and between 0.63 and 0.83 after 50 years. There was no general tendency for emission coefficients to change with animal density or soils type. However, emission coefficients tended to be more variable after application of anaerobically digested MSW than after composted MSW. The low carbon content and high nitrogen content of the former material means that the amount of carbon supplied to the field is small compared to changes in crop production that the relatively large amounts of nitrogen can cause.

\section{Discussion}

Despite the great potential, agroecosystem models have only to a very limited degree been used to assess the environmental impacts of applying composted MSW on agricultural land. Gerke et al. [23] used the Daisy model to estimate the effect of composted MSW on nitrogen leaching, SOM content, and crop production. In agreement with our results, they observed higher nitrogen leaching in scenarios with composted MSW application. Dalemo et al. [39] used results of simulations with the model agroecosystem model 'SoilN' to estimate emission coefficients for the waste management model 'ORWARE' under different Swedish conditions. SoilN is a one-dimensional agroecosystem model simulating plant uptake, mineralization, leaching, and denitrification [40]. The calculated leaching coefficients ranged from 0.06 to 0.60 depending on soil type and drainage flow. These values correspond quite well with the values estimated with Daisy in this study, which ranged from 0.07 to 0.87 when contributions from leaching to the groundwater and losses through the tile drains were added.

The simulated emissions in the current scenarios are within reasonable distance of values observed in experiments conducted under similar conditions. Simmelsgaard [41] observed average leaching rates in the range of 40-104 kg N ha ${ }^{-1}$ year $^{-1}$ for soils with characteristics resembling our sandy soil and from 18 to $42 \mathrm{~kg} \mathrm{~N}$ ha $^{-1}$ year $^{-1}$ for soils resembling our loamy soil. Simmelsgaard and Djurhuus [42] observed an average value of $45.8 \mathrm{~kg} \mathrm{~N}$ $\mathrm{ha}^{-1}$ year $^{-1}$ in a sandy soil and 37.9 in a loamy soil. These values can be compared with the average value of $80.7 \mathrm{~kg}$ $\mathrm{N}$ ha $^{-1}$ year $^{-1}$ on the sandy soil and $31.3 \mathrm{~kg} \mathrm{~N}^{-1}$ year $^{-1}$ on the loamy soil lost through tile drainage and by leaching to the groundwater in the present study. Freibauer and Kaltschmitt [43] reviewed studies estimating $\mathrm{N}_{2} \mathrm{O}$ emissions in Europe. In the "Temperate West" region they found average $\mathrm{N}_{2} \mathrm{O}$ emissions of $1.8 \mathrm{~kg} \mathrm{~N} \mathrm{~N}_{2} \mathrm{O}-\mathrm{N} \mathrm{ha}^{-1}$ year $^{-1}$ and a range of $0-8.0 \mathrm{~kg} \mathrm{~N}_{2} \mathrm{O}-\mathrm{N} \mathrm{ha}^{-1}$ year $^{-1}$. For comparison, the average value in our scenarios was $3.9 \mathrm{~kg}$ $\mathrm{N}_{2} \mathrm{O}-\mathrm{N}$ ha $^{-1}$ year $^{-1}$, with a range of $2.8-5.9 \mathrm{~kg} \mathrm{~N}_{2} \mathrm{O}-\mathrm{N}$ $\mathrm{ha}^{-1}$ year $^{-1}$. Although these rates are within the right range, they still seem to be slightly high on average. Ammonia volatilization on application of manures is very variable and dependent on several different factors [44]. The assumption of the model that $15 \%$ of the applied ammonium is volatilized as ammonia when it is surfaceapplied to a growing crop is probably too simplistic, but a good average. When manure is injected or incorporated 
before sowing, some ammonia still volatilizes. The model assumption that no ammonia volatilizes in this situation is therefore not true, although injection and incorporation of the manure reduces losses significantly [44,45].

The very small variation between the emission coefficients of $\mathrm{N}_{2} \mathrm{O}$ formation after application of the processed organic MSW is due to the fact that the model simulates it as a fraction of the ammonium that is nitrified, reminiscent of the methodology recommended by the IPCC [46] to estimate $\mathrm{N}_{2} \mathrm{O}$ emissions. This also resulted in very small changes in the emission coefficients in the simulations with altered mineralization dynamics in the sensitivity analysis. The range of the emission coefficients of 0.014-0.022 is in correspondence with the IPCC value of 0.0125 of added nitrogen that is eventually emitted as $\mathrm{N}_{2} \mathrm{O}$. However, the variation in ammonia volatilization between scenarios and applied materials is too small due to the simplistic assumptions of the model, although the emissions are of a reasonable magnitude. To develop the model further in this field, a more detailed model describing the formation of anaerobic micro sites as influenced by the presence of organic matter and limited oxygen diffusion may be needed. However, this is not considered to be realistic in the near future.

The timescale at which the impacts are assessed has some influence on the conclusions drawn from the simulations. In the current study the impacts were assessed by simulating 100 years after an application of processed organic MSW, after which almost no differences in emission rates between scenarios with application and the corresponding standard scenario were observed (figure 5). However, even after 100 years there was still a little organic matter left from the original application, producing small differences in emission rates between the two scenarios. The experiments used for calibration of composted MSW decomposition were not very long, the longest lasting for 552 days for $\mathrm{C}$ and 210 days for $\mathrm{N}$, at which point about $95 \%$ of the $\mathrm{C}$ and $78 \%$ of $\mathrm{N}$ was still not mineralized. Therefore, the last part of the mineralization dynamics cannot be expected to be very well described. Furthermore, composted MSW differs very much in quality depending of the origin of the waste, the added bulking agent and maturity. The data we collected from different sources did not seem to differ markedly, mainly because they all related to mature composted MSW. Therefore, the results of the composted MSW simulations are to a certain degree dependent on whether the parameterization used is applicable for the material in question, while the simulations with anaerobically digested MSW must be considered even more uncertain. However, in both cases the sensitivity analysis showed that the simulations were not very sensitive to the mineralization dynamics, and therefore the estimates are still considered useful. A more detailed model relating some sort of quality index such as maturity measures of the added organic matter to the initial distribution of $\mathrm{C}$ and $\mathrm{N}$ to the different model pools may be useful.

The Daisy model has been under development for a long time and must be considered advanced compared to most land application modules of waste management models. However, there are still a number of areas where further development is needed. In addition to the deficiencies already pointed out, the current application showed that further improvement needs to be made regarding production of undersown crops, which are very hard to control.

We constructed a range of realistic scenarios representing situations under which composted and anaerobically digested MSW might be applied. However, the scenarios with applications on farms with high animal density are not realistic in the sense that processed organic MSW is unlikely to be applied in these situations. Nevertheless, we included farms with maximum animal density as the environmental impacts of the applications cannot be expected to be linearly related to animal density. However, we did not observe large increments in the environmental impacts on farms with maximum animal density compared to farms with average density.

The scenarios were, to as high a degree as possible, constructed to be in agreement with the Danish legislation and normal management practices for Danish agriculture. As the regulations and weather and soil conditions change from country to country, these simulation results must be considered specific to Danish conditions and legislation. For example, the regulations concerning the application of waste materials on agricultural fields did not allow any other organic fertilizers to be applied that year, forcing a change in the distribution of organic fertilizers. We tried to perform this redistribution in order to give the smallest reduction in yields, as would a farmer in that situation. However, on some farms a less optimal distribution of the manure in the crop rotations is obtained, resulting in reduced yields and increased nitrogen losses and environmental impacts. Even within Denmark, the results of the simulations are sensitive to the actual situation in which the application is made and only represent examples of what could happen if the application was made under the specific conditions in the scenarios. Therefore, care should be taken when generalizing to other situations or scaling up to larger areas using aerial information of farm and soil types.

\section{Aknowledgement}

This study was conducted with support from DARCOF (Danish Research Centre for Organic Farming) and EULife.

\section{References}

[1] J. Barth and B. Kroeger, Composting progress in Europe, Biocycle 39 (1998) 65-68.

[2] G.M. Evans, Compost quality and market developments, Biocycle 45 (2004) 52-55. 
[3] N. Goldstein, Solid waste composting trends in the United States, Biocycle 44 (2003) 38-44.

[4] EU, Communication from the commission: Towards a thematic strategy on the prevention and recycling of waste, http://europa. eu.int/eur-lex/en/com/cnc/2003/com2003_0301en01.pdf, 2003.

[5] E. Iglesias-Jimenez and C.E. Alvarez, Apparent availability of nitrogen in composted municipal refuse, Biology and Fertility of Soils 16 (1993) 313-318.

[6] F. Amlinger, B. Gotz, P. Dreher, J. Geszti and C. Weissteiner, Nitrogen in biowaste and yard waste compost: dynamics of mobilisation and availability - a review, European Journal of Soil Biology 39 (2003) 107-116.

[7] H.A.J. Hoitink and P.C. Fahy, Basis for the control of soilborne plant pathogens with composts, Annual Review of Phytopathology 24 (1986) 93-114.

[8] A.M. Litterick, L. Harrier, P. Wallace, C.A. Watson and M. Wood, The role of uncomposted materials, composts, manures, and compost extracts in reducing pest and disease incidence and severity in sustainable temperate agricultural and horticultural crop production - a review, Critical Reviews in Plant Sciences 23 (2004) $453-479$.

[9] R. Khaleel, K.R. Reddy and M.R. Overcash, Changes in soil physical-properties due to organic waste applications - a review, Journal of Environmental Quality 10 (1981) 133-141.

[10] P.L. Giusquiani, M. Pagliai, G. Gigliotti, D. Businelli and A. Benetti, Urban waste compost: effects on physical, chemical, and biochemical soil properties, Journal of Environmental Quality 24 (1995) 175-182.

[11] M.R. Carter and B.A. Stewart, Structure and Organic Matter Storage in Agricultural Soils (CRC press, Boca Raton, 1996).

[12] S.E. Tisdell and V.T. Breslin, Characterization and leaching of elements from municipal solid-waste compost, Journal of Environmental Quality 24 (1995) 827-833.

[13] V.T. Breslin, Retention of metals in agricultural soils after amending with MSW and MSW-biosolids compost, Water Air and Soil Pollution 109 (1999) 163-178.

[14] B. Leclerc, P. Georges, B. Cauwel and D. Lairon, A five year study on nitrate leaching under crops fertilized with mineral and organic fertilizers in lysimeters, Biological Agriculture and Horticulture 11 (1995) 301-308.

[15] M. Mamo, C.J. Rosen and T.R. Halbach, Nitrogen availability and leaching front soil amended with municipal solid waste compost, Journal of Environmental Quality 28 (1999) 1074-1082.

[16] H. De Wever, S. Mussen and R. Merckx, Dynamics of trace gas production following compost and $\mathrm{NO}_{3}^{-}$amendments to soil at different initial TOC/NO $\mathrm{NO}_{3}^{-}$ratios, Soil Biology and Biochemistry 34 (2002) 1583-1591.

[17] D. Ginting, A. Kessavalou, B. Eghball and J.W. Doran, Greenhouse gas emissions and soil indicators four years after manure and compost applications, Journal of Environmental Quality 32 (2003) 23-32.

[18] S. Lundie and G.M. Peters, Life cycle assessment of food waste management options, Journal of Cleaner Production 13 (2005) 275-286.

[19] A. Moberg, G. Finnveden, J. Johansson and P. Lind, Life cycle assessment of energy from solid waste - part 2: landfilling compared to other treatment methods, Journal of Cleaner Production 13 (2005) 231-240.

[20] C. Jensen, B. Stougaard and H.S. Ostergaard, Simulation of nitrogen dynamics in farmland areas of Denmark (1989-1993), Soil Use and Management 10 (1994) 111-118.

[21] C.D. Børgesen, J. Djurhuus and A. Kyllingsbaek, Estimating the effect of legislation on nitrogen leaching by upscaling field simulations, Ecological Modelling 136 (2001) 31-48.

[22] J.E. Olesen, G.H. Rubaek, T. Heidmann, S. Hansen and C.D. Borgensen, Effect of climate change on greenhouse gas emissions from arable crop rotations, Nutrient Cycling in Agroecosystems 70 (2004) 147-160.

[23] H.H. Gerke, M. Arning and H. Stöppler-Zimmer, Modelling longterm compost application effects on nitrate leaching, Plant and Soil 213 (1999) 75-92.

[24] S. Hansen, H.E. Jensen, N.E. Nielsen and H. Svendsen, Simulation of nitrogen dynamics in the soil-plant system using the Danish simulation model DAISY, Fertilizer Research 27 (1991) 245-259.

[25] P. de Willigen, Nitrogen turnover in the soil-crop system; comparison of fourteen simulation models, Fertilizer Research 27 (1991) 141-149.

[26] B. Diekkrüger, D. Soendgerath, K.C. Kersebaum and C.W. McVoy, Validity of agroecosystem models: a comparison of results of different models applied to the same data set, Ecological Modelling 81 (1995) 3-29.

[27] P. Smith, J.U. Smith, D.S. Powlson, W.B. McGill, J.R.M. Arah, O.G. Chertov, K. Coleman, U. Franko, S. Frolking, D.S. Jenkinson, L.S. Jensen, R.H. Kelly, H. Klein Gunnewiek, A.S. Komarov, C. Li, J.A.E. Molina, T. Mueller, W.J. Parton, J.H.M. Thornley and A.P. Whitmore, A comparison of the performance of nine soil organic matter models using datasets from seven long-term experiments, Geoderma 81 (1997) 153-225.

[28] S. Bruun, B.T. Christensen, E.M. Hansen, J. Magid and L.S. Jensen, Calibration and validation of the soil organic matter dynamics of the Daisy model with data from the Askov long-term experiments, Soil Biology and Biochemistry 35 (2003) 67-76.

[29] StatBank Denmark, Farms by region and type of farm, http://www. statistikbanken.dk, 2004.

[30] Plantedirektoratet, Vejledning og skemaer 2003/04, http://www. plantedirektoratet.dk, 2003.

[31] DHI, KVL, Dansk Jordbrugsforskning, Watertech, and Landbrugets rådgivningscenter, Standardopstillinger til Daisy-modellen: Vejledning og baggrund, http://www.dina.kvl.dk/ daisy/Daisy_Staabi_ ver_1-0.pdf, 2004.

[32] S.E. Simmelsgaard, Vandbalance og kvælstofudvaskning på 4 jordtyper II - vandbalance, aktuel fordampning og afstrømninig til dræn og undergrund, Tidsskrift for Planteavl 89 (1985) 117-131.

[33] T. Heidmann, J. Nielsen, S.E. Olesen, B.T. Christensen and H.S. Østergaard, Ændringer $\mathrm{i}$ indhold af kulstof og kvælstof i dyrket jord: resultater fra kvadratnettet 1987-1998, DJF Rapport 54 (2001) 1-73.

[34] S. Bruun and L.S. Jensen, Initialisation of the soil organic matter pools of the Daisy model, Ecological Modelling 153 (2002) 291-295.

[35] E.I. Jiménez and V.P. Garcia, Evaluation of city refuse compost maturity: a review, Biological Wastes 27 (1989) 115-142.

[36] J. Leifeld, S. Siebert and I. Kogel-Knabner, Biological activity and organic matter mineralization of soils amended with biowaste composts, Journal of Plant Nutrition and Soil Science 165 (2002) $151-159$.

[37] M. Chodak, W. Borken, B. Ludwig and F. Beese, Effect of temperature on the mineralization of $\mathrm{C}$ and $\mathrm{N}$ of fresh and mature compost in sandy material, Journal of Plant Nutrition and Soil Science 164 (2001) 289-294.

[38] Å. Asdal, T.A. Breland, M.L. Herrero and E. Nordgaard, Frigivningsmønster for plantetilgjengelig nitrogen, KompostkvalitetDokumentasjon og anbefalinger, Planteforsk Grønn Forskning 16, 2002.

[39] M. Dalemo, U. Sonesson, H. Jonsson and A. Bjorklund, Effects of including nitrogen emissions from soil in environmental systems analysis of waste management strategies, Resources Conservation and Recycling 24 (1998) 363-381.

[40] H. Johnsson, L. Bergstrom, P.E. Jansson and K. Paustian, Simulated nitrogen dynamics and losses in a layered agricultural 
soil, Agriculture, Ecosystems and Environment 18 (1987) 333356.

[41] S.E. Simmelsgaard, The effect of crop, N-level, soil type and drainage on nitrate leaching from Danish soil, Soil Use and Management 14 (1998) 30-36.

[42] S.E. Simmelsgaard and J. Djurhuus, An empirical model for estimating nitrate leaching as affected by crop type and the longterm $\mathrm{N}$ fertilizer rate, Soil Use and Management 14 (1998) 37-43.

[43] A. Freibauer and M. Kaltschmitt, Controls and models for estimating direct nitrous oxide emissions from temperate and sub- boreal agricultural mineral soils in Europe, Biogeochemistry 63 (2003) 93-115.

[44] S.G. Sommer and N.J. Hutchings, Ammonia emission from field applied manure and its reduction - invited paper, European Journal of Agronomy 15 (2001) 1-15.

[45] M.N. Hansen, S.G. Sommer and N.P. Madsen, Reduction of ammonia emission by shallow slurry injection: injection efficiency and additional energy demand, Journal of Environmental Quality 32 (2003) 1099-1104.

[46] IPCC, IPCC Guidelines for National Greenhouse Gas Inventories (International Panel of Climate Change, Paris, 1996). 